\title{
How special is medical conscience?
}

\author{
Article
}

Accepted Version

Oderberg, D. S. (2019) How special is medical conscience? The New Bioethics, 25 (3). pp. 207-220. ISSN 2050-2885 doi: https://doi.org/10.1080/20502877.2019.1651078 Available at https://centaur.reading.ac.uk/85333/

It is advisable to refer to the publisher's version if you intend to cite from the work. See Guidance on citing.

To link to this article DOI: http://dx.doi.org/10.1080/20502877.2019.1651078

Publisher: Taylor \& Francis

All outputs in CentAUR are protected by Intellectual Property Rights law, including copyright law. Copyright and IPR is retained by the creators or other copyright holders. Terms and conditions for use of this material are defined in the End User Agreement.

\section{www.reading.ac.uk/centaur}

\section{CentAUR}

Central Archive at the University of Reading

Reading's research outputs online 
How special is medical conscience?

WARNING - AUTHOR'S DRAFT

David S. Oderberg

Department of Philosophy, University Of Reading, Reading, UK

Department of Philosophy Unixercityof Readinc Reading RG66AA.

d.s.oderberg@ reading.ac.uk

CIRCULATION.

SEE ABOVE FOR OFFICIAL

PUBLISHED VERSION. 


\section{How special is medical conscience?}

The vigorous legal and ethical debates over conscientious objection have taken

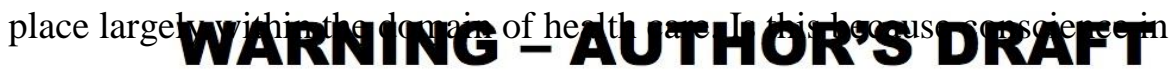
medicine is of a special kind, or are there other reasons why it tends to dominate these debates? Beginning with an analysis of the analogy between medical

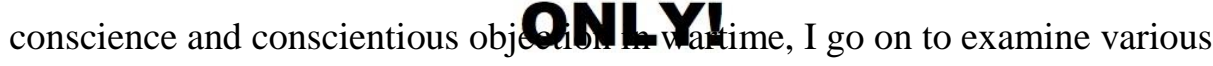
possible grounds for distinguishing between medicine and other professional contexts (taking law principled difference exists between the military and medical cases, nor between the health professions and other professions. Nevertheless, there are practical

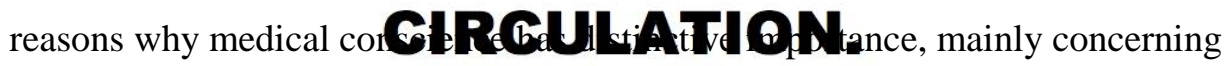
the rapid advance of medical technology. Medical conscience will, for these reasons, continue to drive the debate over conscientious objection, even though legal protection should in principle extend to all professions.

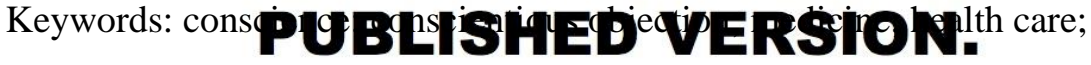 professions}

\section{Introduction}

Within medical ethics there continues to be a vigorous debate about the role of conscientious objection (CO) in health care. ${ }^{12}$ Much of the debate has focused on whether it can be permissible to compromise a health care worker's moral integrity by requiring him to act for or on a patient in a way that violates his principles (Brock 2008; Wicclair 2011: 25-7 and passim; Baylis 2015). There is also disagreement over the extent to which a professedly liberal, pluralistic and democratic state is permitted to coerce practitioners to violate their consciences (Giubilini 2014: 174-5; Murphy and Genuis 2013: 351; Oderberg 2018a, 2018b; Giubilini and Savulescu 2018). Questions of

\footnotetext{
${ }^{1}$ The literature is extensive, but for a representative sample of writers both for and against, see: Savulescu 2006; Asch 2006; Wicclair 2011; Birchley 2012; Giubilini 2014; Neal and Fovargue 2016.

${ }^{2}$ Note that throughout this article, the terms 'medicine'/'medical' and 'health care' will be used interchangeably to denote the full range of health professions.
} 
dignity, respect, tolerance, and liberalism figure large in the debate. ${ }^{3}$ Whether there is something special or peculiar about medicine/health care itself has been less a focus of attention. Is medicine unique, or at least special, in giving rise to problems of

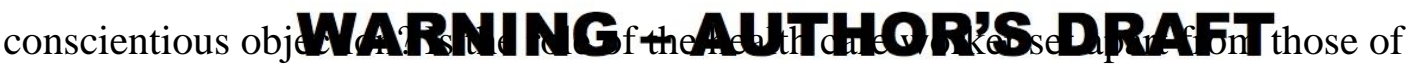
other professions? After all, that the $\mathrm{CO}$ debate has been exclusively about medicine suggests prima facie that there is something particularly sensitive, or perhaps troubling, about the doctor-patient relationship, or about the particular concerns of the profession, NOT FOR CITATION OR

such that problems of conscience, and serious ones, are bound to arise.

In what follows I consideriand whether medicine is a special case when it comes to conscientious objection. First, I will examine the most familiar

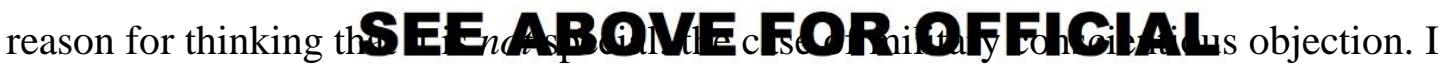
will then move on to analyse a series of other features that might be thought to give health care a special status in the conscience wars. mixed: I will conclude that, although health care is not special in principle, in practice it almost certainly is.

In principle, conscience cases can arise in any profession. The conscientious objections that are raised will be particular to the subject matter of the profession in question. Nevertheless, conscience cases will arise across professions for the same generic reason: conflict between required action and deeply held ethical principles. In practice, however, given that health is a universal good, and given rapid advances in biotechnology, medicine is always likely to stand out as far as the prevalence of conscience objection cases is concerned.

\footnotetext{
${ }^{3}$ An interested recent discussion, in the Australian context, that defends medical conscience on liberal, pluralistic grounds is Howe and Le Mire 2019.
} 
This suggests a two-pronged approach to the defence of professional conscience rights. While health care should remain the focus of attention, and indeed take on even greater urgency for practical reasons, advocates should also pursue the development of a general legal framework for protecting conscientious objection. How this might apply

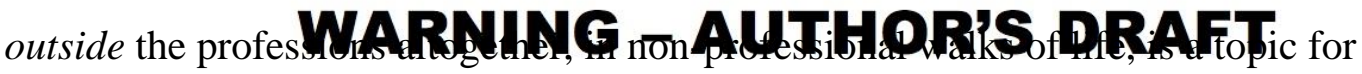
separate investigation.

\section{ONLY!}

\section{The military analogy}

\section{NOT FOR CITATION OR}

As soon as one begins to think of medicine as somehow special when it comes to

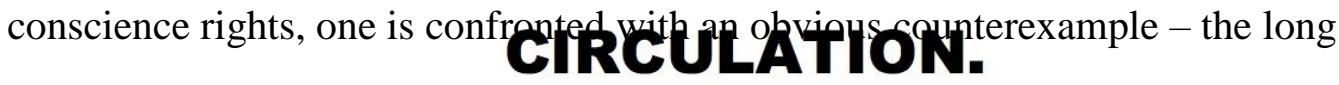
tradition of conscientious objection in wartime. (For an overview, see Goodall 2010.) Does the fact that miSE EOABOUE if not most liberal democracies, make it easier to accept $\mathrm{CO}$ in medicine? The simple argument is that if we acceptents, supreme national emergency, surely we should be prepared to accept medical CO which does not arise in such a dire social circumstance - although the situation may be dire for an individual patient or group of patients. The weakness of this simple argument is that its persuasive force relies on the critic's acceptance of military $\mathrm{CO}$ in the first place. The critic might consistently reject both military and medical CO, though it is worth noting that, in line with the widespread acceptance of conscientious objection in wartime, even the most strident opponents of medical CO stop short of condemning the military equivalent (see, e.g, Giubilini and Savulescu 2018). The strength of the argument lies in its appeal to consistency: if a person may permissibly opt out of some practice in the most extreme of social circumstances, how could they be denied an optout in less extreme circumstances when then general ground of the opt-out request is the same? In both cases, the conscientious objector believes that the behaviour being 
required of them (military or medical activity of some kind) violates deeply held ethical principles. If society or the state accommodates the objector even when the survival of the society or state might be at risk, surely the society or state must accommodate the objector in less onerous circumstances?

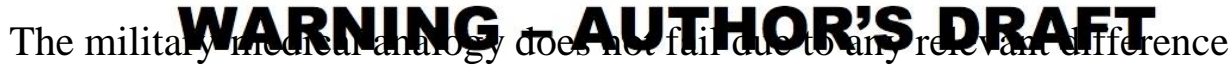

between the professional status of soldier and doctor. The military profession has as ONLY!

much right to that name as the medical profession. Both involve kinds of work that require long and intensive training for the work to be performed skilfully. Both are

heavily regulated. The practice of medicine is governed by national and international

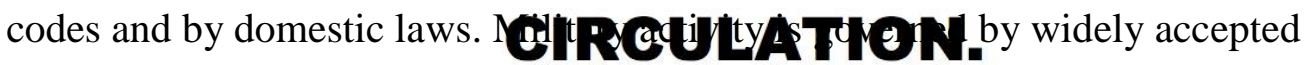
international conventions and rules of conflict supplemented by country-specific

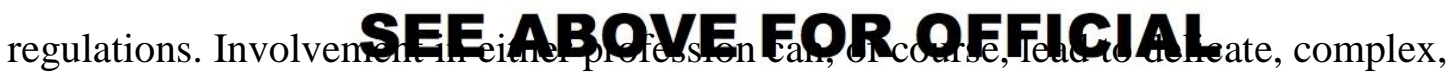
life-or-death decision making - but I hasten to emphasize that in my view this is not a necessary condition for CO to apply to a profession.

\section{PUBLISHED VERSION.}

Critics of medical $\mathrm{CO}$ have said the following about the medical-military analogy: just as $\mathrm{CO}$ in warfare has often led to punishment and ostracism, so in medicine the objector must be prepared to bear the consequences of being allowed an opt-out. As Giubilini and Savulescu (2018) put it: '[c]onscientious objectors to conscription to war were incarcerated or experimented upon. Today's conscientious objectors pay no such costs.' This echoes in much stronger terms the views to which these authors signed up along with a number of other academics in the 'Consensus Statement on Conscientious Objection in Healthcare' (Consensus Statement 2016). For these opponents of medical $\mathrm{CO}$, objectors should only rarely have an exemption, but when they do they 'should be required to compensate society and the health system for their failure to fulfil their professional obligations by providing public-benefitting 
services' (Consensus Statement 2016, point 7). How might the defender of medical conscience respond?

One must with charity assume that Giubilini and Savulescu are not suggesting that medical objectors should be incarcerated or experimented upon, and in any case

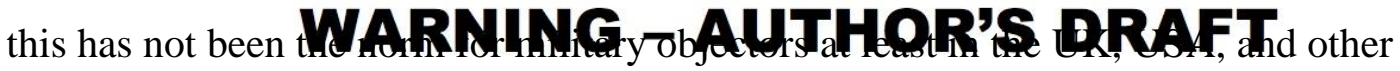
English-speaking countries. To be sure, a certain amount of social ostracism and ONLY! general hostility was once directed toward people who were often regarded as mere cowards. Nevertheless, most military obiectors took on usefuland even vital roles such NOT FOR CITATION OR as medical care for the wounded, agricultural and factory labour, and so on. Some were simply left alone to live in the As a defender of medical CO, I acknowledge that objectors should expect to be treated with a certain animos refusing to 'go with the flow'. Such is the price of non-conformity. This is a long way PUBLISHED VERSION. from saying that military or medical objectors should suffer persecution or discrimination under the law, rather than accommodation in accordance with their legal rights. If $\mathrm{CO}$ is a civil right, then the state must not countenance persecution for its exercise. Ideally, one should also hope for civility and respect at all times, but in such delicate situations as inevitably arise in war and medicine this is not always possible.

Perhaps, as Giubilini implies, it is in the involuntary aspect of military service that the disanalogy with health care lies. The common view among critics of medical $\mathrm{CO}$ is summed up by Udo Schuklenk when he says that '[n]obody forces anyone to become a professional. It is a voluntary choice' (2015: ii). Again, as Julian Savulescu puts it: 'If people are not prepared to offer legally permitted, efficient, and beneficial care to a patient because it conflicts with their values, they should not be doctors' (2006: 294). Although this is a familiar argument, it is difficult to see the force of the 
point. If military CO applied only to conscripts, then 'career soldiers' or volunteers would have no exemptions; however, they too can face situations where conscience requires them to refuse to serve and the law allows such refusal (examples might include what is to them an egregiously unjust war, or seriously unjust behaviour within

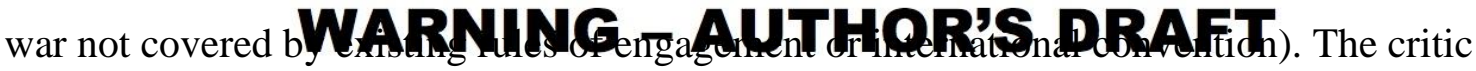
might respond that this is irrelevant, the point being that a military conscientious

ONLY! objector is exempted from serving in a combat role altogether, because of his having been conscripted; no volunteer would request an opt-out from serving in a combat role NOT FOR CITATION OR altogether. Such a response would only prove my point, however: no person who voluntarily 'signs up' to being altogether, only to specific acts that they consider violate their ethical principles.

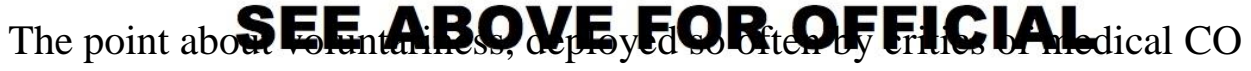

against its proponents, needs to be handled with care. The objection usually takes a

\section{PUBLISHED VERSION.}

simple form: 'The conscript does not volunteer to serve but the doctor willingly enters the profession. This explains why we allow an opt-out for the former but not the latter.' In my view it explains no such thing. It makes a false comparison: in the former case, what we are really concerned with is the conscript's status as citizen, and their right not to serve in a combat role at all, as opposed to being concerned with a soldier's conduct within a combat role. In the latter case, we are concerned with the health care worker's status as health care worker, and their conduct within a profession that they have already signed up to. . Once the structure of the analogy is correctly understood, we can apply it to illuminate the case of medical $\mathrm{CO}$. For it is open to any conscript to renounce their citizenship altogether - as many conscientious objectors do - in order to avoid military service. Similarly, it is open to any health care worker to leave the profession, as critics of $\mathrm{CO}$ continuously urge, if their consciences are troubled by what they are 
sometimes expected to do. Yet it is by no means commonly held that the price of military $\mathrm{CO}$ has to be renunciation of one's citizenship. One could of course be

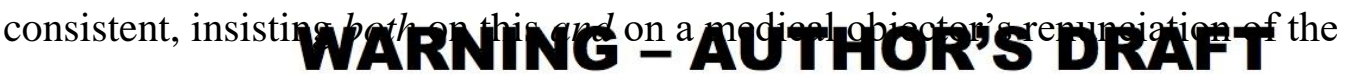
profession, but one would need to argue in favour of such a solution. On the other hand, if freedom of conscience is a basic civ professing tolerance and respect for diversity in ethical codes and world views - as the international conventions to which such states are stghatories make it abundantly clear - then the preferred approach should be to provide conscience-based accommodations in both kinds of case.

\section{CIRCULATION.}

\section{Moral decision making}

\section{SEE ABOVE FOR OFFICIAL}

Perhaps we should consider medicine to be special when it comes to conscience rights PUBLISHED VERSION.

because, as Mary Neal puts it, 'the practice of healthcare necessarily (and perhaps routinely) involves decision-making that contains a moral element' (2019). Adrienne Asch also emphasizes the crucial role of moral decision making in medicine. Curiously, though, she states: 'The idea that, unlike most professionals, health care providers leave their personal moral beliefs at the door when they go to work and simply provide any service that is safe and legal does not reflect the daily experience of medical practitioners or provide a model that society expects them to adhere to' (2006: 11 , emphasis added). On the contrary, one would have thought, given the extent to which health care has dominated recent debates about conscientious objection, that most people considered other professions to be quite different from medicine, and regarded

\footnotetext{
${ }^{4}$ See Article 18 of the United Declarations Declaration on Human Rights 1948 and the various treaty and convention clauses derived from or similar to it, such as Article 9 of the European Convention on Human Rights.
} 
lawyers, accountants, and corporate middle managers (to pick at random) as professionals who do 'leave their personal moral beliefs at the door' when asked to provide a lawful service. Most people are well aware of the delicate ethical decision making involved in health care, where issues of life, death and health are front and

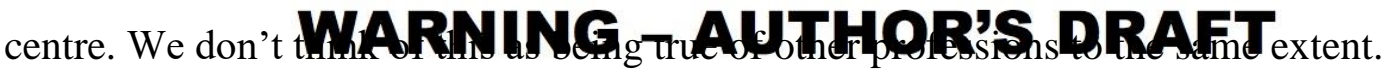

That said, Asch is correct about the inescapable role of moral decision making in ONLY! medicine, and right to hold that society does not and should not expect doctors to park their moral principles before starting work. In principle however this applies across the board. In all professional contexts there are moral decisions to be made, whether the professional involved realizes fact by carrying out a simple thought experiment. All they need to do is ask: 'What is

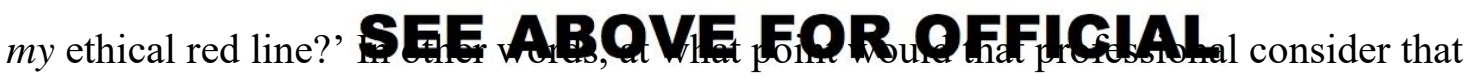
they have been asked to do something that violates their deeply and sincerely held

\section{PUBLISHED VERSION.}

moral principles? Every single professional - unless they are some kind of psychopath or sociopath - will have their ethical red lines, which means that, in principle, problems of conscience might potentially arise for them. Any professional, I submit, should be able to shelter under a general legal framework protecting freedom of conscience in a liberal society. As Asch succinctly puts it: 'We applaud employees who blow the whistle on unsafe or unethical practices in corporations. By conscientiously objecting to practices that are often ingrained in the cultures of their chosen professions, they do society a service'. She goes on: 'A society that accepts pluralism and diversity in its members' religious beliefs and moral commitments should not require people to behave in ways that go against deeply held convictions' (2006: 11).

Note in passing, however, that Asch's elision of whistleblowers and conscientious objectors is a little quick. Whistleblowers intentionally alert others to 
practices that are clearly illegal or that society recognizes as uncontroversially wrong (such as fraud and corruption). Conscientious objectors, by contrast, knowingly (although it is unlikely to be their intention) alert others to the fact that a particular practice is ethically contested, and so is not one that every qualified person should be required to perforWARMANG conscientious objectors perform a service to society.

\section{ONLY!}

Now, the role of conscience in the professions generally might not loom large in practice or in the public imagination. This occurred to me when Irecently suggested the NOTFOR ClTATON OR

following at a workshop on conscience in health care. Imagine a lawyer were asked by

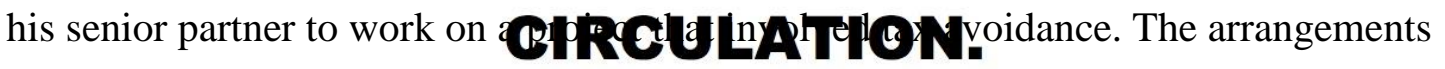
would be perfectly legal, given various technical loopholes, but would clearly violate

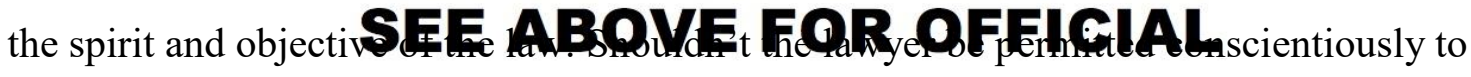
object without fear of demotion, harassment, or other penalty? No sooner had I

\section{PUBLISHED VERSION.}

presented the scenario than a muffled giggle spread throughout the room. The scenario seemed ridiculous to my audience - a lawyer with a troubled conscience! But what the audience reaction suggested to me was that if professional freedom of conscience was taken more seriously across the board, rather than being discussed only in relation to health care, some other professions might claw back some much needed respect. (Even more so if conscience clauses were incorporated into formal, enforceable codes of ethics.) Other examples might include: accountants, who are regularly expected by their employers to sail close to the wind in audits and other work; journalists, who can easily find themselves expected to run with stories that have no evidential basis; and politicians, for whom the expectation to compromise one's principles is a commonplace of climbing the political 'greasy pole'. 
It must be emphasized that accommodation of $\mathrm{CO}$ is not supposed to be a substitute for other mechanisms and processes that help to minimize ethical conflict such as, perhaps, a greater diversity in public and private health care provision. In some cases of conflict, the relevant area of professional practice is so specialized that it is no

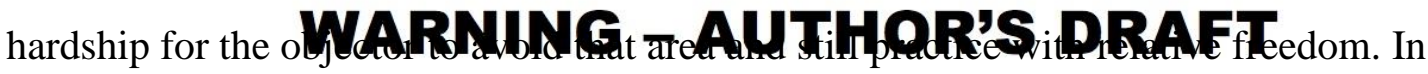
medicine, for instance, it should be possible for a conscientious objector to transgender ONLY! surgery or some other form of extreme body modification to avoid the contested work and still practise cosmetic surgery relatively freely. Bv contrast, an objector to abortion NO'T FOR CITATION OR would have their professional freedom severely restricted by being prohibited from

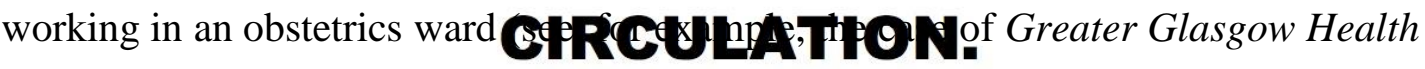
Board v Doogan [2014] UKSC 68). In general, tacit or perhaps even explicit contractual

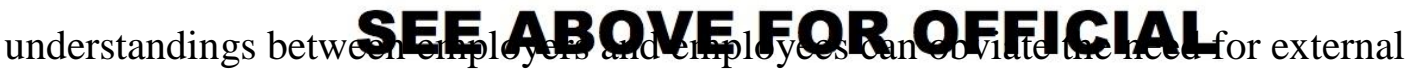
resolution of conscience-based objections. Nevertheless, formal protection for $\mathrm{CO}$

\section{PUBLISHED VERSION.}

within a statutory and common law framework must exist as, to use a currently fashionable term, the ultimate backstop giving real force to the many international agreements recognising freedom of conscience. As a basic civil right in a liberal society, conscience deserves the same explicit legal recognition as other civil rights such as freedom of speech and freedom of association. What could justify differential treatment?

\section{Protecting interests and avoiding harm}

It might be argued that health care involves the promotion and protection of other people's interests in a way not found in other professions. It is not for nothing that 'First do no harm' (from Hippocrates' work Of the Epidemics) is a cornerstone of medicine, along with such principles as these from the Hippocratic Oath: 'I will use my power to help the sick to the best of my ability and judgement; I will abstain from harming or 
wronging any man by it' (Lloyd 1983). Given the centrality in the medical profession of doing good and avoiding harm, we should not be surprised that a health care worker who believes that what they are expected to do will cause harm to their patient, or not do the good that is supposed to be done, might reasonably object to carrying out the task at hand.

\section{WARNING - AUTHOR'S DRAFT}

One immediate response to this suggestion is that although doing good and

\section{ONLY!}

avoiding harm is such a palpable feature of medicine, it is by no means confined to it.

The premise here seems to be that members of some professions are more like service NOT FOR CITATIONOR

providers. Perhaps the question of avoiding harm is more likely to arise when it comes

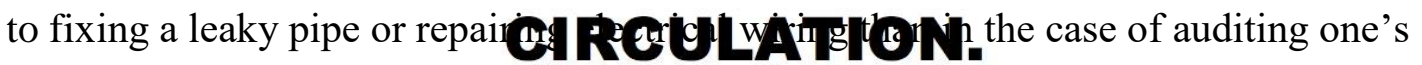
accounts or arranging a property transfer. Certainly harm - at least in a manifest, bodily

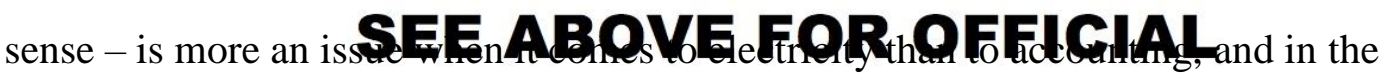
former case the avoidance of harm is hardly likely to give rise to a conscience question.

\section{PUBLISHED VERSION.}

But every profession is dedicated to doing good and avoiding harm, even if the goods and harms at stake are not bodily. A lawyer is bound to avoid putting their client in legal jeopardy, to make all available attempts to keep them from being harmed by state action, or by neighbours, or by business partners. Advancing one's client's legal interests is as much a case of doing good for that client as keeping their blood pressure normal. Avoiding financial injury to a client is the business of an accountant just as avoiding bodily injury is a prime concern of the doctor. An investment adviser, or lawyer, or accountant, should be legally free to opt-out of implementing a scheme rather, a scam - intended to separate clients from their money with no discernible benefit to the client thereby. We should not, then, be misled by the more spectacular, headline-grabbing nature of medicine into thinking that it has a unique occupation with people's interests. 
The second point is that $\mathrm{CO}$ is about more than refusing to do that which might cause harm to one's patient or client. An objector might refuse to do something they consider wrong even though it does not harm, or even benefits, their patient or client. In the legal example, a tax avoidance arrangement is going to benefit the client, yet

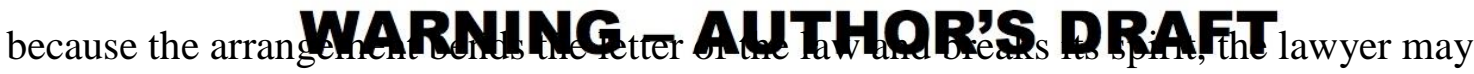
have serious reservations about implementing it. The defender of medicine's unique

\section{ONLY!}

status might draw a distinction here, inasmuch as it is harder to see how a doctor's objection to doing what he believes to be wrong can be separable from his belief that by NOTFOR CITATION OR

doing what he objects to he will be harming the patient. Yet here, again, the contrast with other professions is not s RCULATION.

Suppose a surgeon objects on moral grounds to doing purely cosmetic surgery,

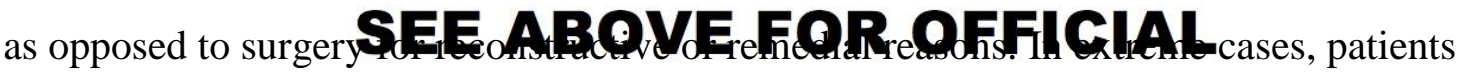
ask to be made to look like Barbie or Ken, or like some celebrity. Now, some surgeons PUBLISHED VERSION. might object to such surgery because they think it is dangerous, exposing the patient to harm, perhaps in the long term. But they need not. The procedure in question might be safe yet some surgeons might still object on the basis that surgery is not about pandering to vanity, fanning the flames of narcissism, promoting 'celebrity culture', and so on. They might think it wrong to operate for non-medical reasons, and this may represent an ethical 'red line' for them, even though the procedure itself would not be harmful to the patient (not even psychologically, at least as far as the surgeon can tell).

This sort of case, I submit, provides a better illustration than the example of abortion of how $\mathrm{CO}$ and harm can come apart in medicine. Most physicians who oppose abortion believe that it involves not only taking the life of the unborn child but also that it harms the patient, at least psychologically and in the long term. Still, it is hardly inconceivable that a physician might have a conscientious objection to abortion solely 
because it involves taking a life and not because they believe it harms the mother in any way. Therefore, it is plausible to think that there is no principled difference between medicine and other professions when it comes to promoting a patient's or client's interests and avoiding harm to them.

\section{WARNING - AUTHOR'S DRAFT}

\section{Trust and integrity}

Alternatively, it might be argued that torghatient relationship involves a unique bond of trust. The patient relies on the practitioner's integrity - their commitment to

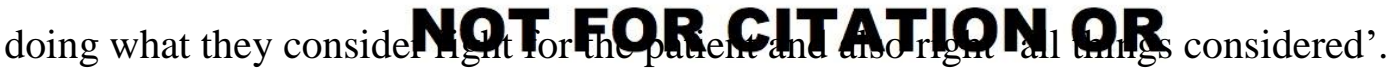

Given this, no patient would want a practitioner to provide a service or treatment to CIRCULATION.

which the latter had a serious ethical objection, if for no other reason than doubt about whether the practitioner would pe sufficiently practised or sufficiently committed to providing it with the utmost skill (Savulescu and Schuklenk 2016: 163).

The thought thPSABA treatments to which they object does not, of itself, distinguish medicine from other professions. On the contrary, a client ought perhaps to be more worried about having a lawyer or accountant implement a tax avoidance scheme to which they ethically objected than about a medical conscientious objector. It is unlikely the sanctions on a lawyer or accountant in such a situation would match the severe discipline meted out to a health care worker who allowed their ethical objections to interference with the actual quality of the service they provided, with all the attendant dangers such interference would produce.

When it comes to trust and integrity, the difference between medicine and other professions, if there is any, can only be a matter of degree. It is of the essence of most professions that clients and patients rely heavily on the knowledge and expertise of the professional. The reason we engage professionals in the first place is that we are unable 
to manage our own situation unaided, whether it be our health, our financial affairs, or our legal difficulties. We expect the professionals we engage to act with integrity in our case: we expect them to be honest, reliable, helpful at all times, on our side, and - we hope - of sufficiently upright character not to let us down. Do we care as much about what is sometimesdARHANG principles? Does it matter to us whether our doctor only does what she believes to be ONLY! ethically correct (whether or not potential harm to the patient is at issue)? Do we worry about whether our lawyer or accountant provides only those services with which they NOT FOR CITATION OR feel ethically comfortable? I doubt that such concerns are high on the list of most patients or clients, but if they orfordesty board. If we expect our health care professionals to behave with a certain amount of

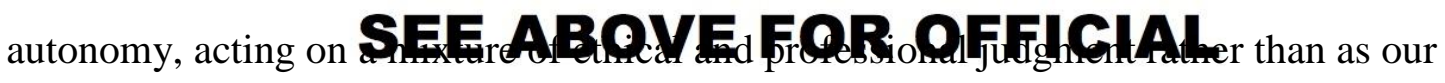
personal valets, then I do not see why we ought not to think the same way about other

\section{PUBLISHED VERSION.}

professions. If it is more common to see one's doctor as an autonomous professional than one's lawyer - who, we might think, is a mere highly paid functionary there to do our bidding - this says more about our respective attitudes to the medical and legal professions than about the nature of those professions.

\section{Intimate and delicate decisions}

Perhaps what is special about medicine is the uniquely intimate and delicate decisions that patients and doctors make in consultation with each other. There are things a person will tell their doctor that they would not tell anyone else except perhaps a priest. Health care professionals are often privy to the most secret and sensitive information about another human being. The potential consequences of acting wrongly on that information are huge, even a matter of life and death. 
Supposing that all of this is true, it is hard to see how it means that there is no place for $\mathrm{CO}$ in other professions. In fact, there is a logical gap between the intimacy and delicacy of the doctor-patient relationship and the need for conscience protection in that profession. How does this aspect of the relationship give rise to conscience rights?

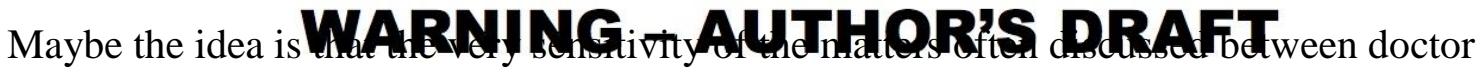
and patient implies the possibility of doctors being pressured or expected to do

\section{ONLY!}

something they regard as seriously wrong. Perhaps, due to the intimacy of the relationship, there is a risk of doctors blurring the need to help with the expectation of NOT FOR CITATION OR

doing whatever the patient wants them to do as long as it is legal, practicable, and does not involve any wrongdoing for Regthit'Aprlogive.

If so, I submit that the difference between the medical scenario and other

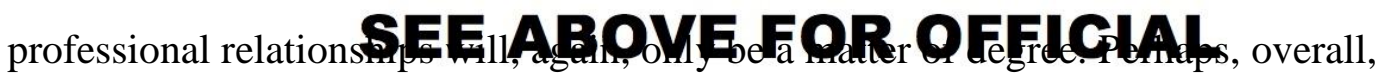
medical decisions are more delicate and sensitive than the decisions made in the context PUBLISHED VERSION. of other professional relationships (legal or accounting decisions, for example). This does not exclude the possibility that a lawyer, for example, might find herself being asked - by her client or by her senior partner - to do legal work of a particularly sensitive nature, sailing very close to the wind of what she considers ethical practice. To be sure, in law, or accounting, or finance, or other related professions, decisions are rarely a matter of life and death or of bodily health and well-being. Yet they can still be highly sensitive, involving the most intimate details of how a person arranges their financial or legal affairs. Delicate judgments regarding what is professionally acceptable can and often do arise.

Mark Wicclair queries the supposedly unique status of health care in relation to other professions. He finds 'questionable' these two claims: (i) '[ $t$ ]he infringement of an agent's moral integrity is much more serious in the case of physicians than in the case of 
employees of accounting firms and advertising agencies'; and (ii) '[t]he impact of the choices and actions of physicians is much greater than that of employees of accounting firms and advertising agencies' (2000: 215). Perhaps he overstates the case a little inasmuch as, in general, the impact of decision making in medicine is probably more

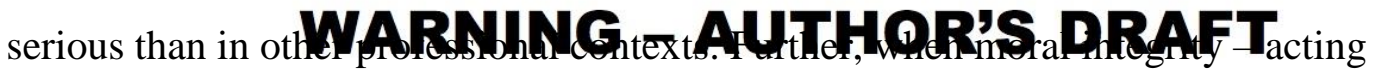
according to one's principles - is at stake, the issues that arise are likely to be more ONLY! serious in health care than in law, accounting, or advertising. Still, Wicclair is right not to see anything unique about medicine, meaning that $\mathrm{CO}$ for other professions should NOT FOR CITATION OR not be ruled out ab initio. Wicclair himself considers an advertising executive tasked

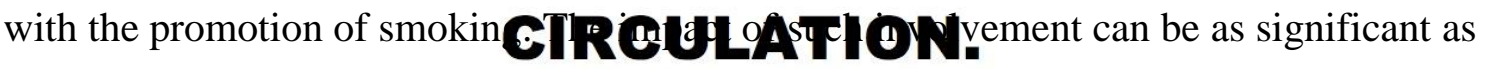
in any doctor-patient relationship, if we are looking at contribution to harm. The advertising executive SEF, ARQYE injury through their participation in the advertising campaign, but such involvement still

\section{PUBLISHED VERSION.}

gives rise to a serious question of conscience. The executive might be troubled by their indirect contribution to harming public health if the campaign were successful, which might be every bit as troubling for the executive as it would be for a doctor asked to do something they believed would indirectly harm their patient.

\section{If not in principle, then in practice}

It has proven difficult to find a line of demarcation between medicine and other professions such that $\mathrm{CO}$ should be available in the former context and not in the others. I have argued that there is nothing about medicine per se that sets apart $\mathrm{CO}$ in that profession from the long-accepted availability of $\mathrm{CO}$ in wartime. Further, what is true of health care is true also of other professions; I have focused on the legal and financial professions, but the same can be said for others such as advertising (Wicclair 2000). All are concerned with promoting the interests of their clients and avoiding harm to them. 
Moral decision making is found in all of them; sometimes the decisions to be made are of great significance for the client or for third parties. All professional relationships involve trust, integrity, reliability, and the sharing of sensitive information. Intimate aspects of a client's life are the subject matter of many professional relationships -

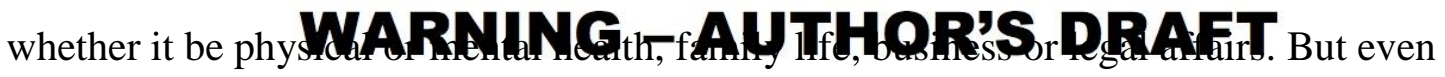
when sensitive or intimate information is not involved, professionals may find their ONLY! consciences troubled by the expectations of their clients, or of their superiors, or by the requirements of the recognized code of practice of their profession. Every member of a profession will have their 'red lines' - the boundaries they will not cross, as a matter of

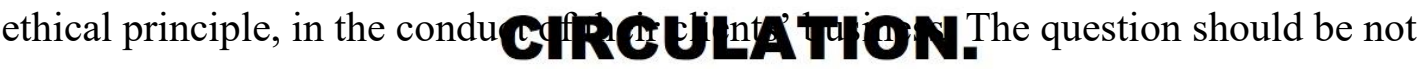
whether there should be legal protection for CO across the professions, but how it should be implement SEE ABQMVE

Nevertheless, despite the lack of a principled line of demarcation between health

\section{PUBLISHED VERSION.}

care and other professional fields, it is no accident that health care dominates debate among ethicists about conscientious objection. High-profile legal cases, such as Doogan, are partly responsible. These, however, reflect a more general preoccupation with beginning- and end-of-life decision making that goes back to the explicit conscience protection of section 4 of the Abortion Act UK (1967), as well as the Church Amendments in the USA (1973) which allow for extensive accommodation of CO to abortion by workers in federally-funded hospitals.

There is, however, a far broader concern that distinguishes the medical profession - and the health care professions in general - from the other professions. This is the rapid, seemingly unstoppable march of technology and the opportunities it creates for treatments, procedures, and services that we can still barely imagine. Indeed, I would go as far as to suggest that it is no more than an historical accident that abortion 
and euthanasia have been the triggers for debate about conscientious objection.

Although beginning- and end-of-life issues will continue to occupy much of the debate

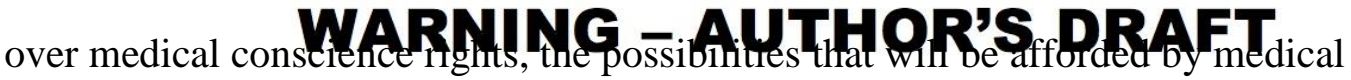
technology over the coming decades make it certain that increasing numbers of medical ONLY!

practitioners will find their own ethical red lines being challenged by patient demand for lawful services, and by thejrmanarérestations

Consider some of the procedures and services that are currently available and becoming increasingly widesp CARGHHATa ONsgender surgery - once a rarity, now more easily available. There is extreme body modification, ${ }^{5}$ cognitive

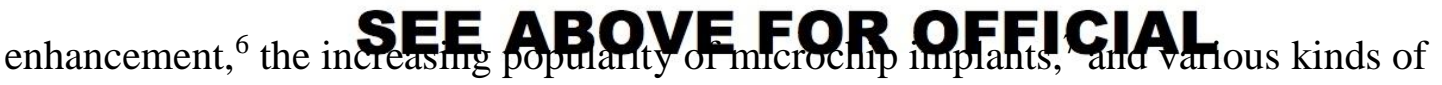
body integrity disorders leading to requests for the removal of health body parts. ${ }^{8}$ Then

\section{PUBLISHED VERSION.}

there is the rapid development of gene editing, ${ }^{9}$ personalized genetic testing, ${ }^{10}$ and an as-yet unimagined range of medical treatments and services that better understanding of the human genome will bring. It would be short-sighted and insouciant to insist that the kinds of activity listed here will be confined to the private sector, where health care professionals might have greater autonomy over whether they wish to participate.

Transgender surgery is available on the NHS; why should we think other procedures will not be, should there be sufficient demand and vigorous lobbying? Nor should we think that such treatments and services will only ever remain niche and are unlikely to trouble the consciences of the vast majority of doctors. First, it is not a question of numbers. Protection for conscience was built into UK abortion legislation

\footnotetext{
${ }^{5}$ For a list of currently available modifications, see https://shrtm.nu/yq4D [last accessed 15/02/19].

${ }^{6}$ See https://shrtm.nu/GqMS for some examples [last accessed 15/02/19].

${ }^{7}$ On which, see https://shrtm.nu/7oYn [last accessed 15/02/19].

${ }^{8}$ See https://shrtm.nu/fjuD [last accessed 15/02/19].

${ }^{9}$ See https://shrtm.nu/dHSD [last accessed 15/02/19].

${ }^{10}$ For background, see https://shrtm.nu/kQG2 [last accessed 15/02/19].
} 
from the beginning, when access to such services was limited and expected by many to remain limited. The question is one of principle: in a liberal, pluralistic democracy that does not profess a single, comprehensive ethical or religious code, may any doctor be compelled to act in violation of their deeply and sincerely held ethical boundaries?

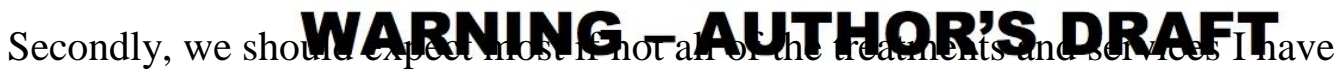
mentioned to become increasingly accessible and affordable. For now, genetic testing is ONLY!

a minority pursuit. Reduced costs, increased accuracy and ease of use, demands from insurance companies, expectations from government and employers and sheer popular interest, will make it a virtual commonplace within a few decades. This will make it harder for doctors to avoid the EPR aribthAtAOS the service themselves or refer patients to another practitioner who will, that they provide information about

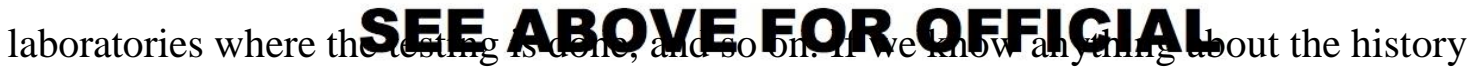
of medicine, it is that what starts off as niche, expensive, difficult, and therefore

\section{PUBLISHED VERSION.}

unpopular, usually becomes widespread, affordable, and much easier to implement. Hope correspondingly metamorphoses into expectation; and expectation has the potential to lead to $\mathrm{CO}$ and the desire for an exemption on the part of those of whom demands are made.

This is not to say that rapidly advancing medical technology will lead to an epidemic of $\mathrm{CO}$ in medicine. Taking all medical treatments, procedures, and services as a whole, it will continue to be the case that the vast majority are either beneficial, or at least not harmful, nor likely to trouble the consciences of any medical professional. That said, it is certain that we will find large areas of health care where conscience cases become increasingly common. Technology has a habit of pushing ethical boundaries, which inevitably leads to questions of conscience for people involved in implementing the technology. The overall direction of travel in society might seem distinctly 
permissive, but in a highly pluralistic society where people hold to various ethical codes (religious or secular), we should not expect everyone to 'go with the flow', least of all

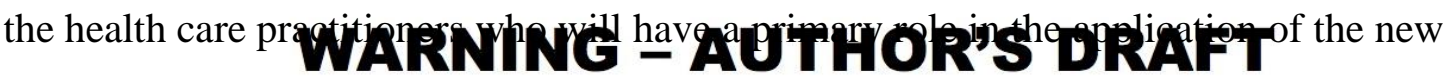
technologies. ${ }^{11}$

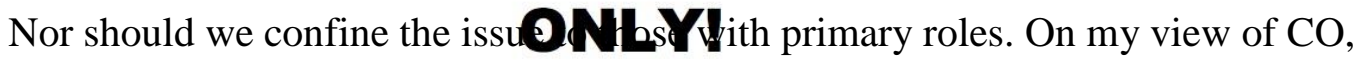
it is essential that the ethics of cooperation be given full weight. ${ }^{12}$ It is the lack of a civil jurisprudence of cooperation, and the overly harrow wordmg of the Abortion Act UK, that led to the failure to protect the midwives in Doogan from having to assist on an CIRCULATION. abortion ward. Legal protection for CO should not be reserved solely for those tasked with performing the ghjeged-ta assisting with performance of the act in ways that are sufficiently direct and proximate to implicate them mor:RUBH possible by advances in medical technology, the question of cooperation will be relevant. In the case of DNA testing, for example, a conscience issue might arise for the doctor with whom the initial consultation takes place, for a technician in the laboratory where such tests are performed - he might conscientiously object to some kinds of DNA tests and not others - or for other professionals, such as consultants or surgeons, who are asked to provide various services based on the test results. The question of cooperation can, in principle, arise at many locations in the causal chain of health care provision.

\footnotetext{
${ }^{11}$ None of which, of course, excludes the important further question of conscience protection for those involved in the design, production, and marketing of technology in respect of which conscience questions might arise.

${ }^{12}$ For full discussion, see Oderberg 2018a. For detailed analysis of specific issues, see Oderberg 2017.
} 


\section{Conclusion}

When it comes to the question 'how special is medical conscience?', then, my answer is twofold: not special in principle, but special in practice. Health care will always be a universal concern of the deepest kind. Nearly all of us need the services of a lawyer or accountant at some time in our tives; but no one, without exception, can live without the need for medical care, and we often need it on more than an occasional basis. This ONLY!

basic, universal need, coupled with extraordinary advances in the scope and variety of

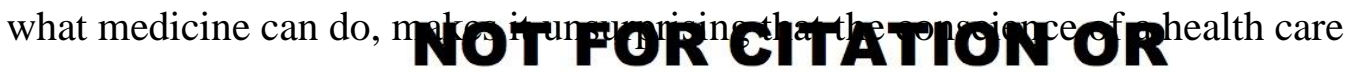
professional is more likely to be challenged than the conscience of a lawyer. The lack of

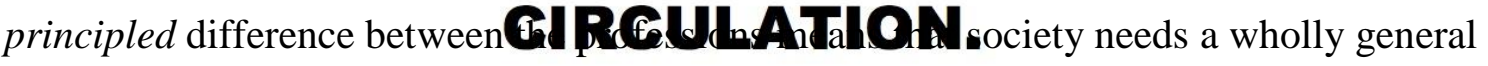
legal framework for conscience protection, combining both statute and case law. At the SEE ABOVE FOR OFFICIAL same time, the clear difference in practice between health care and the other professions means that, with such a framework in place, the details of its interpretation and

\section{PUBLISHED VERSION.}

implementation would, at least in the early stages, be hammered out almost exclusively in the context of medical cases. As such, a serious commitment to legal protection for conscientious objection, in line with international commitments, will make medicine the driver of protections that all professions will be able to enjoy.

\section{References}

Abortion Act. 1967. Abortion Act UK (http://www.legislation.gov.uk/ukpga/1967/87) [last accessed 29/07/19].

Asch, A. 2006. Two cheers for conscience exceptions. Hastings Center Report, 36, pp.11-12.

Baylis, 2015. A relational view of conscience and physician conscientious action.

International Journal of Feminist Approaches to Bioethics, 8, pp.18-36. 
Birchley, G. 2012. A clear case for conscience in healthcare practice. Journal of Medical Ethics, 38, pp.13-17.

Brock, D.W. 2008. Conscientious refusal by physicians and pharmacists: who is obligated to do what, and why? Theoretical Medicine and Bioethics, 29, pp.187200.

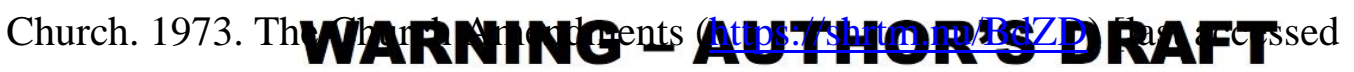
29/07/19].

Consensus Statement 2016. Consensus statement on conscientious objection in healthcare. Practical Ethics: Ethics in the News blog, at https://shrtm.nu/PgQv [last accessed 29/07/19].

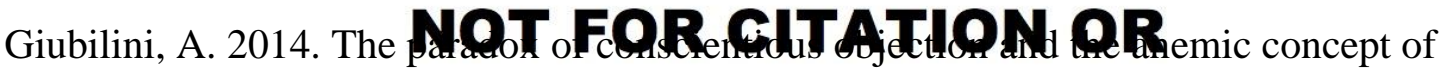
'conscience': downplaying the role of moral integrity in health care. Kennedy

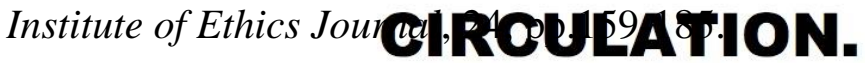

Giubilini, A. and Savulescu, J. 2018. Against Conscientious Objection In Health Care: A Counterdeclaration And Reply To Oderberg. Practical Ethics: Ethics in the
News blog, at https://shrtm.nu/pbzE [last accessed 29/07/19].

Goodall, F. 2010. We will not go to war: conscientious objection during the world wars. Stroud, Glouce RURRLISHEPPYSERSION.

Howe, J. and Le Mire, S. 2019. Medical referral for abortion and freedom of conscience in Australian law. Journal of Law and Religion, doi:10.1017/jlr.2019.14 [last accessed 29/07/19].

Lloyd, G.E.R. ed. 1983. Hippocratic Writings. London: Penguin Books.

Murphy, S. and Genuis, S.J. (2013) Freedom of conscience in health care: distinctions and limits. Bioethical Inquiry, 10, pp.347-54.

Neal, M. 2019. Conscientious objection, 'proper medical treatment', and professionalism: the limits of accommodation for conscience in healthcare. In J. Adenitire ed. Religious Beliefs and Conscientious Exemptions in a Liberal State. London: Hart Publishing.

Neal, M. and Fovargue, S. 2016. Conscience and agent integrity: a defence of conscience-based exemptions in the health care context. Medical Law Review, 24, pp.544-570.

Oderberg, D. S. 2017. Further clarity on cooperation and morality. Journal of Medical Ethics, 43, pp.192-200. 
Oderberg, D.S. 2018a. Opting Out: Conscience and Cooperation in a Pluralistic Society. London: Institute of Economic Affairs.

Oderberg, D.S. 2018b. Response from David S. Oderberg to "Against Conscientious Objection In Health Care: A Counterdeclaration And Reply To Oderberg”. Practical Ethics: Ethics in the News blog, at https://shrtm.nu/wLmC [last accessed WARNING - AUTHOR'S DRAFT

Savulescu, J. 2006. Conscientious objection in medicine. British Medical Journal, 332, pp.294-297.

ONLY!

Savulescu, J. and Schuklenk, U. 2016. Doctors have no right to refuse medical assistance in dying, abortion or contraception. Bioethics, 31, pp.162-70.

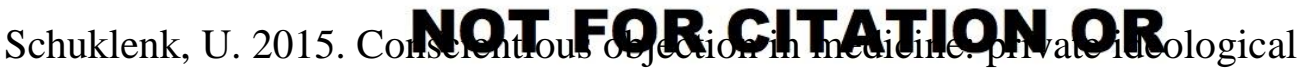
convictions must not supercede public service obligations. Bioethics, Editorial, 29, pp.ii-iii. CIRCULATION.

Wicclair, M.R. 2000. Conscientious objection in medicine. Bioethics, 14, pp.205-27.

Wicclair, M.R. 2011. Conscientious gbjection in heglth care Cambridge, UK: Cambridge University Press. 